\title{
7
}

\section{Information Technology in China}

\author{
FENG SHAN, CAI JUN, LI TONG \\ Department of Automatic Control Engineering, \\ Institute of Systems Engineering, \\ Huazhong University of Science and Technology, \\ Wuhan, Hubei, P.R. China
}

\begin{abstract}
The paper consists of four sections relevant to information technology in China. An overview of the information technology trend and its multi-dimensional impact on the development process of the country has been given in the introduction. Then to cope with the challenges of the technological applications and outcomes, the problem of the shortage of qualified workers has been raised and the prevailing unsatisfactory curricula both for managers and information engineers are outlined and discussed. In the last section, an alternative concept of information is explained.
\end{abstract}

\section{Keywords}

Information technology, education, curriculum, management training program

\section{INTRODUCTION}

The rapid technological developments of the last 25 years have brought us to the "era of cyberspace(, a time of global changes in the way of life of modern society. China was isolated from the influence of these developments until the end of the 1970s; it has been involved deeply since that time.

In late 1978 China introduced reforms that changed the orientation of its industrialisation drive, a development usually referred to as China's "Opening up" to the outside world. This has allowed China to exploit opportunities provided by access to foreign capital, technology and markets. Within a relatively short period of 15 years, China has managed to transform itself from an underdeveloped economy into one of the fast growing New Industrialising Economies (NIEs), and its economic management has been shifting gradually from command planning to a market-based economy. At the same time, China's top leaders have highlighted the need for China to catch up with developed countries in some fields of science and 
technology. Information is one of the seven chosen key fields which would exert long-term influence on the national economy. The new imported information technology has occupied an increasingly larger share of the information (products and services) market. While its use has in many ways facilitated China's economic development, it has also met problems that need to be solved systematically, among the most important, a shortage of trained personnel. Our educational system must devise an advanced curriculum to provide specialists who can understand, interpret, and apply the new information technology.

\section{CHALLENGES AND PROBLEMS}

In China, the central government recognises clearly that information technology (hereafter, IT) has become the most important strategic technology for international competition, due to its rapid development and extended applications. Further, it understands that IT is a "multiplier" for economic development and a "catalyst" for social progress, having a significant impact on economic construction, social evolution and national safety. Management system reform and structural transformation of the Chinese economy depend heavily on the quality and quantity of inputs of labor and resources. China should lose no opportunity to develop and to speed up the application of new technology. This will improve the country's economic growth and strengthen its competitiveness in world markets.

Now, in China, IT is considered to be a key field which will exert long-term influence on the country's development, and it has been chosen as one of the target fields of the country's hightech program the "863 Programme". In the past 10 years, this program has sponsored hundreds of IT research projects. This research work has trained a lot of young scientists and technicians. In the Outline of the Ninth Five-Year Plan for National Economy and Social Development and the Long-Term Target for the Year 2010, which was endorsed by China's top legislative body recently, IT has been emphasised as the key program. So, we can expect that China's IT research and application, as well as IT education, will be accelerated to ensure that the planned development goals are achieved.

However, China still has a long way to go to keep pace with the world's advanced IT. There is a significant gap between planning and implementation. On one hand, IT has in many ways brought about great progress in our society, e.g. "internets" links China with the outside world, "full service network (FSN)" helps enterprises to gain advantage over their competitors and do business efficiently. On the other hand, there is an increasingly urgent demand for workers equipped with IT skills to handle the information systems. And there is also a new class of tasks for governmental departments to cope with cases of "computer crimes" and "spiritual pollution", for example. Therefore, skilled staffs are wanted. Consequently, there is a big shortage of managers and/or officers trained in IT and its applications in our enterprises and offices.

Nevertheless, in China, our educational system has not produced an effective curriculum to enable students to fulfil the new class of tasks, which must be done by the tools of information processing, e.g., information resource management systems, system modeling and implementation etc., in addition to the necessary domain-specific knowledge and experience. So far, students graduated from Chinese universities and colleges have not been educated in these categories. Several supplementary ways to solve the curricular problems have been tested: on the job training, i.e. sending managers to computer school for a period, and promoting the computer programmer or operator to be business information officer, that is learning by doing. However, since the learning process is not systematically organised and 
designed, the trainees (capability and performance often does not fit the job requirements. And taken as a whole, the situation causes a considerable reduction in management efficiency, and in fact, it may slow down the pace of China's system reform and opening up.

It is the authors' purpose to attend the Conference to identify and to study successful examples of educational programs to train IT personnel in our country.

\section{THE IT CURRICULA IN CHINA}

Below, we show two courses of study in parallel to compare the subjects taught to undergraduate students majoring in business management and information engineering, respectively. These curricula are in use at Huazhong University of Science and Technology, one of the leading universities in China and also one directly administered by the State Education Commission. These curricula are representative of China's IT education.

From Table 1, it is clear that information engineer students are not offered with courses of IT application in the area of business and management. In their optional course, "Microcomputer application and design", they are not taught how to use management information software. This may be their only chance to learn something about IT application. But in fact, what they learn is so simple that it can not satisfy that practical requirement. On the other hand, very little knowledge of IT can be learned by the students of business management. Most of their compulsory subjects are theoretical, and time to practice with IT is rarely provided for them in the course. The only subject offering IT knowledge is "Modern management information systems". It can be seen that the credit for this course is only about one-tenth of the total credits. But in fact, it should be the objective of this course to impart the knowledge and skills required by business management students to design, implement and manage information systems in a commercial or administrative environment.

In the past few years, the university has begun to make some attempts at rearranging the curricula for students of the two majors, in order to equip them with IT knowledge and management knowledge. One of the measures being tested makes selected courses available to the students of both majors. Obviously, this measure provides opportunities for some students to become bi-professional. But the shortage of managers and officers qualified in IT has not been remedied. Effective and efficient teaching methods, curriculum innovation, should be explored and tested, based on the successful experiences of the developed countries.

\section{AN ALTERNATIVE VIEW OF INFORMATION TECHNOLOGY}

In the last section of this paper, the authors would like to share their ideas about information technology from a historical and social point of view, such that we may treat the evolution of technology properly. 
Table 1 Curriculum Sample

\begin{tabular}{|c|c|c|c|c|}
\hline $\begin{array}{l}\text { Department } \\
\text { College } \\
\text { Objective Professional } \\
\text { Degree } \\
\text { Course Duration }\end{array}$ & $\begin{array}{l}\text { Electronics and Information Engi } \\
\text { Information Science \& Engineeri } \\
\text { Information Engineer } \\
\text { MSE } \\
11 \text { Compulsory Subjects } \\
27 \text { Credits plus Selective 3-6 Cred }\end{array}$ & $\begin{array}{l}\text { ineering } \\
\text { ing } \\
\text { dits }\end{array}$ & $\begin{array}{l}\text { Information Systems } \\
\text { Business Administration } \\
\text { Business Manager } \\
\text { MBA } \\
9 \text { Compulsory Subjects } \\
26 \text { Credits plus Selective } 3-6 \text { Crec }\end{array}$ & \\
\hline & Subject & Credit & Subject & Credit \\
\hline $\begin{array}{l}\text { CP1 } \\
\text { Compulsory Public } \\
\text { CP2 } \\
\text { CP3 } \\
\text { CP4 } \\
\text { CP5 }\end{array}$ & $\begin{array}{l}\text { Scientific socialism theory and } \\
\text { practice } \\
\text { Dialectics } \\
\text { First foreign language } \\
\text { Applied function analysis } \\
\text { Theory of matrix }\end{array}$ & $\begin{array}{l}2 \\
4 \\
2 \\
3\end{array}$ & $\begin{array}{l}\text { Scientific socialism theory and } \\
\text { practice } \\
\text { Dialectics } \\
\text { First foreign language }\end{array}$ & $\begin{array}{l}2 \\
4\end{array}$ \\
\hline $\begin{array}{l}\text { CF1 } \\
\text { Compulsory Fundamental } \\
\text { CF2 } \\
\text { CF3 } \\
\text { CF4 }\end{array}$ & $\begin{array}{l}\text { Image processing and analysis } \\
\text { Digital language processing } \\
\text { Pattern recognition }\end{array}$ & $\begin{array}{l}3 \\
3 \\
3\end{array}$ & $\begin{array}{l}\text { Economics of management } \\
\text { Operations research } \\
\text { Statistics of management }\end{array}$ & $\begin{array}{l}3 \\
3 \\
3\end{array}$ \\
\hline $\begin{array}{l}\text { CS1 } \\
\text { Compulsory Selective } \\
\text { CS2 }\end{array}$ & $\begin{array}{l}\text { Chinese culture review } \\
\text { Eastern philosophy and } \\
\text { modernisation }\end{array}$ & 1 & $\begin{array}{l}\text { Chinese culture review } \\
\text { Eastern philosophy and } \\
\text { modernisation }\end{array}$ & 1 \\
\hline $\begin{array}{l}\text { SLl } \\
\text { Optional Selective }\end{array}$ & $\begin{array}{l}\text { Microcomputer application } \\
\text { and design }\end{array}$ & 1 & Financial accounting & 3 \\
\hline SL2 & Digital communication & 3 & Business management & 3 \\
\hline SL3 & Statistical signal analysis & 2 & Production management & 3 \\
\hline SL4 & Image data compression & 2 & Economic laws & 3 \\
\hline SL5 & Artificial intelligence & 2 & $\begin{array}{l}\text { Modern management } \\
\text { information systems }\end{array}$ & 3 \\
\hline SL6 & Multi-media technology & 2 & $\begin{array}{l}\text { Development and management } \\
\text { of human resources }\end{array}$ & 3 \\
\hline SL7 & Computer networks & 2 & $\begin{array}{l}\text { Strategic management of } \\
\text { enterprises }\end{array}$ & 2 \\
\hline SL8 & Diagnostics & 2 & Macroeconomics & 2 \\
\hline SL9 & Image data processing & 1 & Knowledge right & 2 \\
\hline SL10 & Second foreign language & 1 & Marketing & 2 \\
\hline SL11 & & & Tax theory and practices & 2 \\
\hline
\end{tabular}

\subsection{What is information?}

Information is commonly used in three ways: (1) in a semantic sense as data; (2) in the pragmatic sense of knowledge; and (3) in a formal technical sense as the resolution of doubt or uncertainty. It should be emphasised that, while knowledge is inherently an anthropocentric concept, information is technically defined in terms of an abstract observer. Information in the third (Shannonian) sense of the word is a function of the a priori probability of selecting a given state or outcome from the universe of physically possible states. The more physically possible states there are, the more information is embodied in a given selection or set of equivalent selections (for detail refer to Shannon, C.E., 1948, 1949). 


\subsection{What is information technology?}

To make information technology (IT hereafter) an item easier to understand, let us link IT with biological terms. That Organisms capture disembodied information from the environment and store it in physical structures has been pointed out in various ways many times (Polar, 1961). The gene itself is nothing more nor less than a packet of information stored compactly in molecular from (Schrodinger, 1945). It contains both morphological and functional information needed by the organism. The information embodied in genes tells cells how and when to divide, how and when to differentiate, how to manufacture various enzymes, hormones, etc. It also tells the organism as a whole how to react to various stimuli, what food to eat, when and how to mate, where to lay eggs, etc. This information store house is the result of a long evolutionary learning process, described by Darwin as natural selection and by Eigen (1971) as value maximisation. The cumulative nature of the process is evident from the fact that the higher organisms carry far more information than the simplest, earliest organisms. The ability of higher organisms to accumulate and reproduce this information by extragenetic means can also be regarded as evidence of increasing "intelligence(in the sense of the ability to learn, to modify behaviour, and/or to modify the external environment, i.e. to create external structures (cultures and cultural artefacts) for information storage. The ability to modify the external environment is apparently possessed to some extent by all higher animals, but the ability to create external structures explicitly for information storage, is possessed only by humans. Evolution seeks to maximise the ability to capture, more importantly to convert some of it to morphological information embodied as structure or organisation. To this extent, that intelligence enhances this ability, and evolution seeks to maximise intelligence. In information technology, the processed information is defined as knowledge, and the condensed knowledge is defined as intelligence. Intelligence and knowledge drives our human society ever forward to an advanced future.

\subsection{Why information technology is so important to us?}

Information technology is an essential factor for the development of human society. The economic system as a self-organising dissipative structure is actually an ever changing structure of information aimed at maximising the utilisation of resources. Although humans may have existed as a distinct biological species for several million years, the processes of extragenetic information storage began only about 6000 years ago. Recently, cultural information accumulation and transfer has been enhanced by the use of computers and undoubtedly surpasses the genetic transfer process.

To this point, we view the development process of human society as the accumulation of "stored information as structure". There are five key mechanisms of the structure: (1) persistence, (2) self-replication, (3) environmental modification, (4) self-modification (learning) and (5) social evolution. Self-replication and environmental modification are both mechanisms for information storage and transfer; self-modification (i.e. learning) and persistence are relevant to long-term survival mechanisms. And social evolution is derived from these mechanisms. 


\section{REFERENCES}

Jaakkola, H. et al. (1995 edited) Information Modelling and Knowledge Bases, VI.

Aamodt, A. and Komorowski, J. (1995, edited) Scandinavian Conference on Artificial Intelligence-95.

Shannon, C. E. (1948) A Mathematical Theory of Communication. Bell System Technical Journal 27.

Shannon, C. E. and Weaver, W. (1949) The Mathematical Theory of Communication. University of Illinois Press, Urbana.

Polar, S. (1961) Evolution and the Thermodynamic Imperative. Human Biology 33(2): 99109.

Schrodinger, E. (1945) What is Life? The Physical Aspects of the Living Cell. Cambridge University Press, London.

Eigen, M. (1971) Self-organisation of Matter and the Evolution of Biological Macromolecules. Die Naturwissen Schaften 58(Oct.).

\section{BIOGRAPHY}

Feng Shan Professor of Systems Engineering in the Department of Automatic Control Engineering and Institute of Systems Engineering, Huazhong University of Science and Technology, Wuhan, Hubei, PRC. She graduated from Beijing Tsinghua University in 1957, with majors in Electrical Engineering and Industrial Automation. She received the M.A. degree in Mathematical Economics and Demography in 1982 from the State University of New York at Stony Brook, USA. Her research and teaching activities include the development and application of computer and systems analysis techniques to information processing systems and intelligent decision support systems. She has published extensively, with more than 60 referred publications. She has presented invited papers and lectures at numerous conferences and workshops. In the past few years, she has averaged about ten presentations/publications per year.

Cai Jun received the B. S. degree in electronic engineering from Suzhou University, Suzhou, P.R. China, in 1987. Currently, he is a Ph. D. candidate of Systems Engineering in Huazhong University of Science and Technology, Wuhan, China. His research interests encompass the theory and application of neural networks, fuzzy logic and evolutionary computation.

Li Tong received the M.S. degree in Huazhong University of Science and Technology, Wuhan, China, in 1994. He is now a Ph. D. candidate of Systems Engineering in Huazhong University of Science and Technology. His current research interests are in the areas of artificial intelligence and intelligent decision support systems. 